\title{
Tissue density determines the water storage characteristics of crop residues
}

\author{
Akhtar Iqbal • Johnny Beaugrand • \\ Patricia Garnier • Sylvie Recous
}

Received: 2 May 2012 / Accepted: 25 July 2012 / Published online: 3 October 2012

(C) The Author(s) 2012. This article is published with open access at Springerlink.com

\begin{abstract}
Background and aims The water storage properties of plant residues play an important role in the regulation of water retention and water transport in no-till agricultural soils. The objective of this work was to understand how the characteristics of crop residues determine their water absorption and retention properties.

Methods A range of eleven undecomposed crop residues and maize stem residue of different particle sizes at three stages of decomposition were characterized regarding their physical and chemical features. Water
\end{abstract}

Responsible Editor: Eric Paterson.

A. Iqbal $\cdot$ J. Beaugrand $\cdot S$. Recous $(\bowtie)$

INRA, UMR614 Fractionnement des AgroRessources et Environnement,

51100 Reims, France

e-mail: sylvie.recous@reims.inra.fr

\section{A. Iqbal $\cdot$ J. Beaugrand}

Université Reims-Champagne Ardenne, UMR614

Fractionnement des AgroRessources et Environnement, 51100 Reims, France

P. Garnier

INRA, UMR1091 Environnement et Grandes Cultures, 78500 Thiverval-Grignon, France

P. Garnier

AgroParisTech, UMR1091 Environnement et Grandes Cultures,

78500 Thiverval-Grignon, France immersion for varying periods of time was used to determine the kinetics of water absorption and the maximal water storage for each type of residue.

Results The immersion time required to reach an equilibrium moisture content varied greatly according to the residue type, ranging from 6 to $30 \mathrm{~h}$ at $20^{\circ} \mathrm{C}$. The maximal water content ranged from 1.28 to $3.81 \mathrm{~g}$ $\mathrm{H}_{2} \mathrm{O} \mathrm{g}^{-1}$ dry residue for undecomposed residues and increased with increasing decomposition. The proportions of cellulose, hemicellulose and lignin in the plant cell walls did not explain the water storage capacities. Differences in porosity, resulting from different tissue densities and the creation of pores during decomposition, were highly correlated with differences in water storage properties.

Conclusions The tissue density of plant residues, which can be inferred from simple characteristics of residue mass and volume, is a relevant criterion for explaining the maximal water storage capacity of plant residues.

Keywords Chemical composition Decomposition · Mulch · Moisture content $\cdot$ Porosity

\section{Introduction}

Water harvesting is one of the most important problems in agriculture, especially in semi-arid regions, but also in many other crop production systems. Conservation agriculture is based on agricultural practices involving 
minimum disturbance of soil, retention of crop residues, such as mulch, and the improvement of crop rotations. In these systems, crop residues that are retained as mulch at the soil surface increase the $\mathrm{C}$ retained in the top soil, modulate the soil temperature, enhance water infiltration, reduce the loss of soil through erosion, capture rain water and decrease the loss of water from the soil through evaporation (Bussiere and Cellier 1994; Baumhardt and Jones 2002; Fuentes et al. 2011). Savabi and Stott (1994) demonstrated that mulch crop residues, an organic porous type of media, can store significant amounts of water, while Coppens et al. (2007) showed that the water storage capacity of rye and rape residues was modified during their decomposition. Crop residues vary strongly in their physical and biochemical features according to the plant species, plant organ and environmental conditions during plant growth. Several authors (Bartholomew and Norman 1946; Myrold et al. 1981; Quemada and Cabrera 2002) have observed differences in the maximum water contents of different plant residues. However, there are few studies addressing the relationship between the maximum water content and crop residue characteristics in agricultural systems (Quemada and Cabrera 2002). In plant ecology, litter characteristics (morphological, anatomical and chemical traits) are used to explain the water content of leaves or roots in annual and perennial grass species (Garnier and Laurent 1994; Cornelissen et al. 2003). In other domains, such as biocomposites and wood technologies, it is well understood that plant cells are composed of hydrophilic (hemicelluloses and cellulose) and hydrophobic (lignin) compounds combined in a cohesive network, which influences water retention characteristics (Pejic et al. 2008; Callum et al. 2009). At the molecular level, these biopolymers can harbor chemical structures that facilitate water retention due to variations in the hygroscopy of the biopolymers, as illustrated for hemicellulose (Zhang et al. 2011). At the cell wall level, water retention can be influenced by the presence of micro- and mesopores that occasionally open or close and become saturated with water. Finally, at the tissue or organ level, macrovoids, which are typically cell wall lumina, influence water retention (Almeida and Hernandez 2006).

It is well established that the chemical composition of plant residues changes during decomposition in soil (Trinsoutrot et al. 2000; Bertrand et al. 2006); however, there are few studies addressing the water retention properties of plants during decomposition (Dresboll and Magid 2006). The water storage characteristics of crop residues are extremely important parameters for modeling the decomposition of crop residues, particularly when residues are left at the soil surface under notill conditions (Findeling et al. 2007). Changes in water storage characteristics could be the result of both structural and chemical transformations that occur during decomposition.

Therefore, the objectives of this study were to understand the relationship between the water storage properties of crop residues and their intrinsic characteristics. We hypothesized that either physical properties (morphology, size and density) or chemical features (biochemistry of the plant cell wall), or both, would determine water storage properties. We chose to work with a variety of crop stems representing residues of eleven different plants that vary according to their botanical family, morphology and maturity stage. We also investigated the effects of changes in the chemical and physical characteristics of stems due to decomposition in soil and how these characteristics change the water storage properties of plants.

\section{Materials and methods}

\section{Selection of crop residues}

The range of crop residues was chosen from conservation agriculture fields in four areas: intensive agriculture in northern France, organic farming in the Rhône-Alpes region of France, family farming in a Cerrados area (Minas Gerais, Brazil), and upland rice cropping systems in the Central Highlands of Madagascar. We selected residues from eleven crops as representatives of these cropping systems: Maize (Zea mays), Wheat (Triticum aestivum), Pea (Pisum sativum), Soybean (Glycine max), Sunflower (Helianthus annus), Stylosanthes (Stylosanthes guianense), Dolichos (Vigna unguiculata), Alfalfa (Medicago sativa), Brachiaria (Brachiaria ruziziesens), Canola (Brassica napus) and Rice (Oriza sativa). Rice and Brachiaria were sampled previously at an experimental site in Brazil and chemically characterized (Abiven et al. 2005). Dolichos and Stylosanthes were sampled at an experimental site of Alaotre Lake in Madagascar. The other residues were sampled on farmers' plots in France. 
Preparation and chemical characterization of crop residues

All residues were collected at the time of harvesting (at physiological maturity), with the exception of alfalfa, which was harvested at the green stage (this crop represented a cover crop). The residues were dried at $40{ }^{\circ} \mathrm{C}$ until constant weight was achieved, then stored. Only the stem of each residue was selected for experimental use. The internodes were recovered after discarding the nodes to minimize the biochemical and physical heterogeneity of the residue fragments. The internodes were cut into $5 \mathrm{~cm}$ pieces using scissors. The $5 \mathrm{~cm}$ size reflected the decimeter range in straw length encountered under field conditions (Angers and Recous 1997). While cutting the stems, we took care that the stem morphology was respected, as we hypothesized that the stem morphology plays an important role in water absorption.

A sub-sample of each residue was ground and analyzed to determine chemical and biochemical characteristics. The soluble fraction was determined using hot water extraction $\left(100^{\circ} \mathrm{C}\right)$ for $30 \mathrm{~min}$ followed by extraction with a neutral detergent $\left(100^{\circ} \mathrm{C}\right)$ for $60 \mathrm{~min}$ (Lineres and Djakovitch 1993). The hemicellulose, cellulose and lignin fractions were subsequently determined using proximate analysis (Goering and Van Soest 1970). From these analyses, the NDF fraction was calculated as the sum of the hemicelluloses, cellulose and lignin present. The Lignocellulose Index (LCI) was calculated as the ratio between the lignin fraction and the sum of the cellulose, hemicellulose and lignin fractions (Herman et al. 2008). This index expresses the proportion of lignin in the plant cell wall. The residue quality was also expressed as the ratio of the soluble and the lignin fractions. The total $\mathrm{C}$ and $\mathrm{N}$ contents of the plant residues were determined via total combustion using an elemental analyzer (NA 2000, Fisons Instruments, Milan, Italy).

Physical characterization of crop residues

Geometry was assigned to each residue stem particle (e.g., cylinder, parallelepiped) to calculate the particle volume and density. In Fig. 1, a schematic diagram of maize internodes is presented as an example. The diagram shows that the internodes are composed of two portions, consisting of porous pith or core and rigid bark. The particles were assigned the geometrical shape of a cylinder with ellipsoid-shaped ends. The geometrical shapes of dolichos, stylosanthes, soybean, alfalfa, brachiaria, sunflower, rice and canola were considered as cylinders, while wheat and pea were considered as hollow cylinders.

The volume of the maize stem particle was calculated using the formula for the volume of an ellipsoid form:

$V=\pi a b L$

where $a$ and $b$ represents the dimension of the section, and $L$ is the length of the particle (Fig. 1).

The volume of cylinders was calculated using the following formula:

$V=\pi r^{2} h$

where $r$ is the radius of the cylinder, and $h$ is the length of the residue particle.

The volume of the hollow cylinders was calculated using the following formula:

$V=\pi h\left(R^{2}-r^{2}\right)$

where $R$ is the radius of the outer surface; $r$ is the radius of the inner surface; and $h$ is the length of the residue particle.

The mass and volume of the stem residues were expressed per unit length (in meters).

Experimental design for decomposition incubation

Due to the presence of maize crop in most of the agricultural situations studied, maize stems were selected as an experimental model to study the effect of decomposition on water storage properties,. The maize internodes were cut into fragments of three different sizes: $5 \mathrm{~cm}$ in length (T5), $2 \mathrm{~cm}$ in length (T2) and $0.5 \mathrm{~cm}$ in length (T0.5). The original morphology was preserved for all samples. The particles of the three different sizes were incubated in soil to obtain residue particles at different degrees of decomposition at the same sampling time. Incubation was performed under controlled conditions. The soil used in these experiments, sampled from the $0-10 \mathrm{~cm}$ layer at the INRA experimental station in northern France $\left(49^{\circ} 80^{\prime} \mathrm{N}, 3^{\circ}\right.$ $60 ' \mathrm{E}$ ), was a silty loam comprised of $17.8 \%$ clay, $77.3 \%$ silt, $3.8 \%$ sand, and $0.95 \%$ organic C, with a $\mathrm{pH}_{\mathrm{H} 2 \mathrm{O}}$ of 7.6 (Machinet et al. 2009). The moist soil was sieved through a 2-mm mesh-size sieve and stored 
Fig. 1 Schematic diagram representing the geometry of maize stem particles 0.5 , 2 and $5 \mathrm{~cm}$ in length
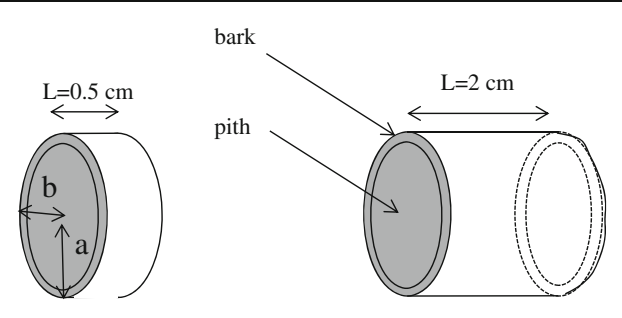

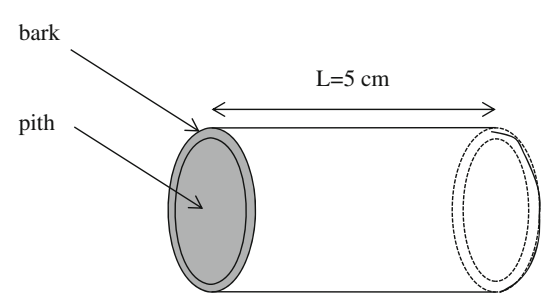

at $4{ }^{\circ} \mathrm{C}$ until the initiation of incubation. The maize stem particles were incorporated into wet soil at a rate of $4 \mathrm{~g} \mathrm{C}$ $\mathrm{kg}^{-1}$ of dry soil and incubated for 105 days at $25 \pm 1{ }^{\circ} \mathrm{C}$ in $3 \mathrm{~L}$ glass jars. The stem particles were removed by hand from the soil at day 0 (undecomposed residue), day 49 and day 105 after the initiation of incubation. The adhering soils were gently cleaned from the residues using a soft brush, so that the surface of the particles would not be altered during manipulation. The particles were dried at $40{ }^{\circ} \mathrm{C}$ for 1 week (to avoid altering their chemical composition during drying).

Maximal and minimal water content measurements

In accordance with previous studies addressing the water retention of fibers (e.g., Ferrero 2003), the equilibrium moisture content (EMC) was defined as the moisture content after which a given residue does not absorb more water at a given temperature and humidity (Bartholomew and Norman 1950). The capillary rise method was used to check the wettability of synthetic fibers; however, this method is not suitable for an intact stem because it would take several days to reach the equilibrium moisture content, favoring decomposition, which would modify the storage properties. Therefore we used an immersion principle method. The time required for each type of residue to reach this equilibrium moisture content is referred to as the immersion time (IT). The maximal water content (MaxWC) was calculated from the EMC as the difference between the initial particle weight (determined at $40{ }^{\circ} \mathrm{C}$ ) and the maximal wet weight after immersion, expressed per $\mathrm{g}$ of dry residue at $40{ }^{\circ} \mathrm{C}$. The minimal water content (MinWC) was calculated as the difference between the water content of particles dried at $40^{\circ} \mathrm{C}$ and $120^{\circ} \mathrm{C}$, expressed per $\mathrm{g}$ of dry residue at $40{ }^{\circ} \mathrm{C}$.

The EMC of the plant stems was measured using methodology based on the immersion principle following Tostado (1996), Myrold et al. (1981) and Quemada and Cabrera (2002), with some modifications.
Tostado (1996) immersed plant residues in water for 15 h, while Myrold et al. (1981) and Quemada and Cabrera (2002) immersed the residues overnight. However, as the characteristics of the different residues varied greatly and might affect the rate of water absorption, it was necessary to check the protocol for all residues to ensure that the immersion time was sufficiently long to reach an equilibrium moisture content. Initially we determined the duration of immersion for each type of residue. The dry residue particles (with 2 replicates per type of residue) were placed at $40{ }^{\circ} \mathrm{C}$ for $24 \mathrm{~h}$ to standardize the initial humidity conditions; subsequently, the particles were weighed, and their volume was determined. The stems were immersed in deionized water for increasing periods of time and weighed periodically to determine the kinetics of water absorption until a constant wet weight was obtained. The wet weight was measured after gentle shaking by hand to remove excess water. Next, we applied the protocol to each type of residue, using 8 replicates to accurately calculate the mean value and standard error of the MaxWC. The minimal water content of residue particles was obtained by placing the wet particles at MaxWC in an oven at $40{ }^{\circ} \mathrm{C}$ until reaching constant weight, then at $120{ }^{\circ} \mathrm{C}$ until constant weight was achieved again (Table 1).

Water retention curves determination using the pressure extractor method

The residue particles were dried at $40{ }^{\circ} \mathrm{C}$ for $24 \mathrm{~h}$ to standardize the initial water content. Then, the particles were immersed in an $\mathrm{NaClO}$ solution $(0.05 \mathrm{M})$ for $2 \mathrm{~h}$ at $4{ }^{\circ} \mathrm{C}$ for sterilization to avoid decomposition during the measurement period (Garnier et al. 2004). After this treatment, the particles were immersed in deionized water until they reached their maximum water retention. The saturated particles were placed on a saturated porous plate inside a pressure chamber. The porous plate was covered with kaolinite to ensure hydraulic 
Table 1 Chemical and physical characteristics of crop residue particles. NDF is the sum of three cell wall components (cellulose+hemicellulose+lignin). The lignocellulose index (LCI) is calculated as the ratio of lignin to the cellulose+hemicellulose +lignin fractions. SOL/LIG is the ratio of soluble fraction to the lignin fraction. Determination of dry mass, volume and density of residue particles was performed with 8 replicates per treatment (mean \pm standard errors)

\begin{tabular}{|c|c|c|c|c|c|c|c|c|c|c|c|}
\hline \multirow[t]{2}{*}{$\begin{array}{l}\text { Crop stem } \\
\text { residue }\end{array}$} & Soluble & $\begin{array}{l}\text { Hemi- } \\
\text { cellulose }\end{array}$ & Cellulose & Lignin & $\mathrm{NDF}$ & LCI & $\mathrm{SOL} / \mathrm{LIG}$ & $\mathrm{C} / \mathrm{N}$ & \multirow{2}{*}{$\begin{array}{l}\text { Dry mass } \\
\text { at } 40{ }^{\circ} \mathrm{C} \\
\mathrm{g} / \mathrm{m}\end{array}$} & \multirow{2}{*}{$\begin{array}{l}\text { Volume } \\
\mathrm{cm}^{3} / \mathrm{m}\end{array}$} & \multirow{2}{*}{$\begin{array}{l}\text { Density } \\
\mathrm{g} / \mathrm{cm}^{3}\end{array}$} \\
\hline & $\mathrm{g} / \mathrm{kg} \mathrm{DM}$ & & & & & & & & & & \\
\hline Wheat & 75 & 271 & 510 & 143 & 924 & 0.15 & 1.24 & 109.1 & $0.97 \pm 0.23$ & $2.86 \pm 0.84$ & $0.35 \pm 0.08$ \\
\hline Rice & 306 & 352 & 301 & 40 & 693 & 0.06 & 7.66 & 30.3 & $1.74 \pm 0.63$ & $6.22 \pm 1.09$ & $0.28 \pm 0.07$ \\
\hline Brachiaria & 220 & 355 & 348 & 74 & 777 & 0.10 & 2.98 & 26.6 & $2.38 \pm 0.33$ & $4.70 \pm 0.84$ & $0.51 \pm 0.06$ \\
\hline Maize & 388 & 190 & 314 & 99 & 603 & 0.13 & 3.92 & 158.5 & $19.99 \pm 3.62$ & $192.9 \pm 39.83$ & $0.10 \pm 0.01$ \\
\hline Soybean & 183 & 171 & 414 & 230 & 815 & 0.28 & 0.80 & 63.1 & $5.03 \pm 0.82$ & $14.29 \pm 2.47$ & $0.35 \pm 0.03$ \\
\hline Pea & 321 & 152 & 422 & 103 & 677 & 0.15 & 3.12 & 56.5 & $0.87 \pm 0.37$ & $5.23 \pm 1.57$ & $0.17 \pm 0.05$ \\
\hline Alfalfa & 182 & 177 & 391 & 248 & 816 & 0.30 & 0.73 & 60.8 & $2.62 \pm 0.45$ & $4.49 \pm 0.92$ & $0.59 \pm 0.05$ \\
\hline Dolichos & 227 & 215 & 390 & 168 & 773 & 0.22 & 1.36 & 53.5 & $10.70 \pm 1.42$ & $23.42 \pm 3.09$ & $0.46 \pm 0.03$ \\
\hline Stylosanthes & 245 & 163 & 457 & 126 & 746 & 0.17 & 1.95 & 46.4 & $1.34 \pm 0.21$ & $5.41 \pm 0.60$ & $0.25 \pm 0.03$ \\
\hline Sunflower & 175 & 174 & 477 & 166 & 817 & 0.20 & 1.05 & 161.3 & $35.45 \pm 6.92$ & $307.8 \pm 48.57$ & $0.12 \pm 0.03$ \\
\hline Canola & 280 & 156 & 443 & 114 & 713 & 0.16 & 2.45 & 72.2 & $8.73 \pm 1.16$ & $60.02 \pm 10.61$ & $0.15 \pm 0.02$ \\
\hline
\end{tabular}

conductivity between the residue particles and the porous plate (Garnier et al. 2004). Once the particles reached equilibrium with the water pressure head, they were weighed. The water retention curve was constructed using the mean values of the water contents measured at $-50 \mathrm{~cm},-100 \mathrm{~cm},-500 \mathrm{~cm},-1,000 \mathrm{~cm},-3,160 \mathrm{~cm}$ and $-15,000 \mathrm{~cm}$ of water for approximately $24 \mathrm{~h}$ using 3 replicates. Because of the large range of water potential, the values obtained for the water retention curve are often expressed logarithmically using the common unit $\mathrm{pF}$, which is equal to the decimal logarithm of the absolute value of the head of water expressed in centimeters.

\section{Pore size distribution}

Cloutier and Fortin (1991) calculated the water pressure head according to the pore size distribution (Young- Laplace equation) in wood material, using:

$\Psi m=-\frac{2 \gamma V w \cos \theta}{r}$

where $\Psi \mathrm{m}=$ the water pressure head $(\mathrm{J} / \mathrm{kg}) ; \gamma=$ the surface tension of water $(\mathrm{N} / \mathrm{m}) ; \mathrm{V}_{\mathrm{w}}=$ the specific volume of water $\left(\mathrm{m}^{3} / \mathrm{kg}\right)$; $\mathrm{r}=$ the radius of curvature of the air-water interface into the capillaries (m); and $\theta=$ the contact angle between the liquid and the surface of the capillary. In the formula given above, each water pressure head represents a certain class of water pores: $-50 \mathrm{~cm}$ (>29.12 $\mu \mathrm{m}),-100 \mathrm{~cm}(14.56-29.12 \mu \mathrm{m}),-500 \mathrm{~cm}$ $(2.91-14.56 \mu \mathrm{m}),-1,000 \mathrm{~cm}(1.45-2.91 \mu \mathrm{m})$, $-3,160 \mathrm{~cm}(0.46-1.45 \mu \mathrm{m})$ or $-15,000 \mathrm{~cm}(0.097-$ $0.46 \mu \mathrm{m})$.

Calculation of porosity (p) from relative density

The plant stem is a cellular and porous material, similar to wood (Kollmann and Cote 1968), composed of cell wall substances and cavities containing air and extracavities (Tsoumis 1991). The relative density (without cavities and intercellular spaces) of the cell wall materials is virtually constant for all timbers with a specific gravity of $1.53 \mathrm{~g} \mathrm{~cm}^{-3}$. This value is a potential physical value for a lignified cellulosic cell wall, which is completely nonporous (Usta 2003). We adopted the formula proposed by Kellog and Wangaard (1969) to calculate porosity using the relative density. They assumed that the mass of cell wall material $(\mathrm{K})$ can be calculated as a function of the wood density (d) as

$K=d / 1.53$

The porosity was calculated from the mass of the actual cell wall material as

$P=1-K$ 
Mathematical curve fitting for the rate of water absorption

Little information is available regarding the propensity of plant residues to undergo water recharge, which is an important parameter in modeling water dynamics (Findeling et al. 2007). While it is possible to obtain information on the maximum and residual water contents experimentally, the propensity of a residue to undergo water recharge can only be obtained via mathematical fitting of the observed data. A non-linear equation using a two-parameter single exponential rise to a maximum was used:

$f=a\left(1-\exp ^{-b x}\right)$

where $a$ represents the value of the plateau of the curve (estimated MaxWC), and $b$ represents the propensity of a residue particle to undergo water recharge.

\section{Data treatment and analysis}

One-way ANOVA was used to analyze the MaxWC obtained from the different residues. To analyze the effects of decomposition and particle size on MaxWC, one-way ANOVA was used with Least Significant Differences (LSD) at the 0.05 probability level. A Pearson correlation was used to examine the relationships between different chemical and physical characteristics of the crop residue particles and their MaxWC, MinWC and IT to reach maximum water retention, estimated maximum water content $(a)$ and residue propensity to undergo water recharge $(b)$. These analyses were performed using SigmaPlot software.

\section{Results}

Biochemical and physical characteristics of undecomposed stem residues

The biochemical and physical characteristics of the stem residue particles are given in Table 1 . The chemical composition varied widely, with the soluble fraction representing from $75 \mathrm{~g} / \mathrm{kg} \mathrm{DM}$ (wheat) to $388 \mathrm{~g} / \mathrm{kg}$
DM (maize), hemicellulose content from $152 \mathrm{~g} / \mathrm{kg}$ DM (pea) to $355 \mathrm{~g} / \mathrm{kg} \mathrm{DM}$ (brachiaria), cellulose content from $301 \mathrm{~g} / \mathrm{kg} \mathrm{DM}$ (rice) to $51 \mathrm{~g} / \mathrm{kg} \mathrm{DM}$ (wheat), and lignin content from $4 \mathrm{~g} / \mathrm{kg}$ DM (rice) to $248 \mathrm{~g} / \mathrm{kg} \mathrm{DM}$ (alfalfa). The plant cell wall content (NDF) ranged from $603 \mathrm{~g} / \mathrm{kg}$ DM (maize) to $924 \mathrm{~g} / \mathrm{kg} \mathrm{DM}$ (wheat). The lignocellulose index (LCI) and the soluble:lignin ratio (SOL:LIG) ranked the stem residues differently and inversely. The two indices were significantly related, with a negative exponential relationship $\left(R^{2}=-0.67, p<0.05\right)$.

The crop stems also showed large differences in their physical properties. The mean dry linear mass ranged from $0.87 \mathrm{gm}^{-1}$ (pea) to $35.45 \mathrm{gm}^{-1}$ (sunflower) at $40{ }^{\circ} \mathrm{C}$ (Table 1). The volume of the stem particles ranged from $2.86 \mathrm{~cm}^{3} \mathrm{~m}^{-1}$ for wheat to $307.80 \mathrm{~cm}^{3} \mathrm{~m}^{-1}$ for sunflower stems. All stems exhibited a density of less than $1 \mathrm{~g} \mathrm{~cm}^{-3}$, with the lowest density observed for maize and sunflower and the highest density observed for alfalfa and brachiaria (Table 1).

Kinetics of water absorption and maximum and minimal water contents of residue particles

The kinetics of water absorption were determined for the stems of each type of residue. Two contrasting examples are shown in Fig. 2. For the alfalfa stems, the IT to reach the EMC was $10 \mathrm{~h}$, while for the canola stems, the IT was $16 \mathrm{~h}$. The IT required to reach saturation varied greatly between the different residue stem particles, ranging from $6 \mathrm{~h}$ for rice stems to $30 \mathrm{~h}$ for maize stems (Table 2). The mathematical model used to fit the observed data provided the parameters $a$, which represents the value of the plateau of the curve (estimated MaxWC), and $b$, which represents the propensity of the residue particle to undergo water recharge (Fig. 2). The maximum value for $a$ was obtained for pea $(a=$ 4.05 ), while the minimum value was obtained for alfalfa $(a=1.01)$. The maximum value for $b$ was obtained for rice $(b=0.77)$, and the minimum value was obtained for maize $(b=0.06)$ (Table 2). The best correlations between the estimated and measured water absorption kinetics were obtained for canola and brachiaria $\left(r^{2}=0.99\right.$ for both), while the minimum $\mathrm{r}^{2}$ value was obtained for sunflower $\left(r^{2}=0.58\right)$ (Table 2$)$; these values were highly significant for all treatments $(P<0.0001)$, except for the value of $b$ parameter obtained for maize $(p<0.0003)$.

The MaxWC differed significantly $(p=0.05)$ between the residue types, resulting in the formation of 


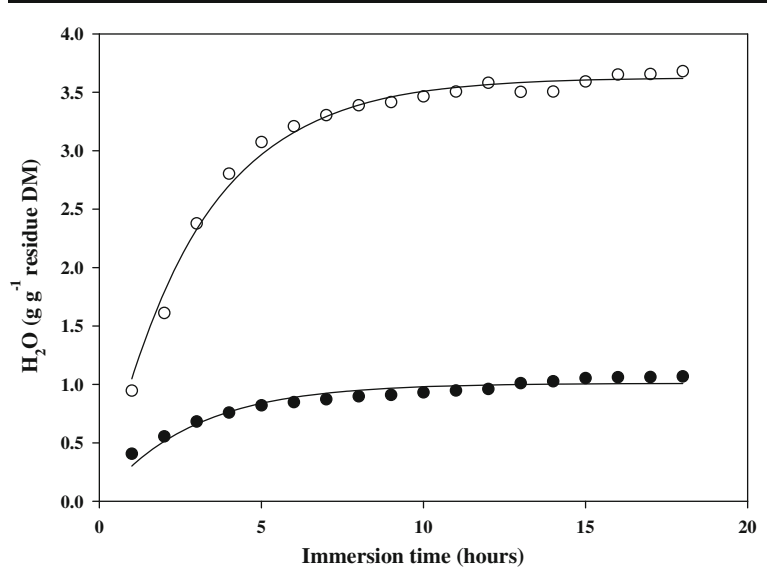

Fig. 2 Kinetics of water absorption of $5 \mathrm{~cm}$ particles of alfalfa (Black Circle) and canola (White Circle) residues. Observed data (symbols) and fitted curves (lines) using the equation $\mathrm{f}=\mathrm{a}\left(1-\exp ^{-\mathrm{bx}}\right)$.

three groups (Table 3). The group presenting the highest values contained sunflower, pea, canola and maize stems, which ranged from 3.10 to $3.81 \mathrm{~g} \mathrm{H}_{2} \mathrm{O} \mathrm{g}$ residue DM, with no significant differences being detected between them, and their values were significantly higher than those of the other residues. The second group contained wheat, rice, soybean, stylosanthes and brachiaria particles, for which the MaxWC ranged from 1.81 to $2.33 \mathrm{~g} \mathrm{H}_{2} \mathrm{O} \mathrm{g}^{-1}$ residue DM. The third group consisted of alfalfa and dolichos particles, which showed the lowest values (1.28-

Table 2 Maximal water content, minimal water content and immersion time to reach the MaxWC value for crop residue particles $5 \mathrm{~cm}$ in length immersed in deionized water at $20{ }^{\circ} \mathrm{C}$. The mean of 8 replicates per treatment and standard errors are given. Estimated parameters of the model $\mathrm{f}=\mathrm{a}\left(1-\exp ^{-\mathrm{b} . \mathrm{x}}\right)$ fitted
$1.32 \mathrm{~g} \mathrm{H}_{2} \mathrm{O} \mathrm{g}^{-1}$ residue DM) (Table 2). The MinWC ranged from $0.035 \mathrm{~g} \mathrm{H}_{2} \mathrm{O} \mathrm{g} \mathrm{g}^{-1}$ residue $\mathrm{DM}$ for rice to $0.067 \mathrm{~g} \mathrm{H}_{2} \mathrm{O} \mathrm{g}^{-1}$ residue DM for brachiaria. The MinWC varied moderately among the crop residues; a group composed of brachiaria, alfalfa, sunflower and canola showed significantly higher values compared with the other residues (Table 2).

Relationship between initial residue characteristics and water content

The relationship between the initial characteristics of the stems and their water storage properties were expressed using Pearson correlations (Table 3). We did not find any significant relationship between the MaxWC or IT with any of the biochemical parameters, except for the $\mathrm{C} / \mathrm{N}$ ratio, which was positively correlated with MaxWC $\left(r^{2}=0.65, P=<0.05\right)$. C/N was also positively correlated with dry matter $\left(r^{2}=0.81, P=<0.01\right)$ and volume $\left(r^{2}=\right.$ $0.86, P=<0.001)$ of the stems, and this correlation mainly results from the high dry mass and volume of the maize and sunflower stems, which also exhibit a high $\mathrm{C} /$ $\mathrm{N}$ ratio. The dry matter and volume were positively correlated with each other $\left(r^{2}=0.98, P=<0.001\right)$, and the volume $\left(r^{2}=0.69, P=<0.05\right)$ and density $\left(r^{2}=-0.90\right.$, $P=<0.001)$ were correlated with MaxWC. The $b$ parameter, which was calculated via fitting, was closely and negatively correlated with IT, as expected $\left(r^{2}=0.85\right.$,

to the experimental data on residue water absorption kinetics, where $a$ is the maximum water content (value reached at the plateau of the curve), and $b$ is the propensity of the residue to undergo water recharge

\begin{tabular}{|c|c|c|c|c|c|c|}
\hline \multirow[t]{2}{*}{ Crop residue } & Maximal water content & Minimal water content & \multirow{2}{*}{$\begin{array}{l}\text { Immersion time } \\
\text { Hour }\end{array}$} & \multirow{2}{*}{$\begin{array}{l}\mathrm{a} \\
\mathrm{g} / \mathrm{g}\end{array}$} & \multirow[t]{2}{*}{$\mathrm{b}$} & \multirow[t]{2}{*}{$r^{2}$} \\
\hline & $\mathrm{g} \mathrm{H}_{2} \mathrm{O} / \mathrm{g} \mathrm{DM}$ & & & & & \\
\hline Wheat & $2.33 \pm 0.46$ & $0.057 \pm 0.027$ & 16 & $2.49 \pm 0.10$ & $0.31 \pm 0.05$ & 0.69 \\
\hline Rice & $2.01 \pm 0.30$ & $0.035 \pm 0.021$ & 6 & $2.29 \pm 0.07$ & $0.77 \pm 0.10$ & 0.91 \\
\hline Brachiaria & $1.81 \pm 0.30$ & $0.067 \pm 0.005$ & 16 & $1.98 \pm 0.03$ & $0.18 \pm 0.01$ & 0.99 \\
\hline Maize & $3.10 \pm 1.12$ & $0.042 \pm 0.004$ & 30 & $3.21 \pm 0.17$ & $0.06 \pm 0.01$ & 0.97 \\
\hline Soybean & $2.16 \pm 0.39$ & $0.052 \pm 0.002$ & 20 & $2.55 \pm 0.15$ & $0.10 \pm 0.01$ & 0.93 \\
\hline Pea & $3.31 \pm 0.72$ & $0.046 \pm 0.010$ & 8 & $4.05 \pm 0.11$ & $0.60 \pm 0.07$ & 0.88 \\
\hline Alfalfa & $1.28 \pm 0.04$ & $0.058 \pm 0.002$ & 10 & $1.01 \pm 0.02$ & $0.35 \pm 0.02$ & 0.92 \\
\hline Dolichos & $1.32 \pm 0.11$ & $0.048 \pm 0.004$ & 24 & $1.12 \pm 0.03$ & $0.16 \pm 0.01$ & 0.94 \\
\hline Stylosanthes & $2.04 \pm 0.22$ & $0.044 \pm 0.007$ & 16 & $2.19 \pm 0.05$ & $0.22 \pm 0.02$ & 0.90 \\
\hline Sunflower & $3.81 \pm 1.03$ & $0.064 \pm 0.004$ & 20 & $3.42 \pm 0.10$ & $0.33 \pm 0.05$ & 0.58 \\
\hline Canola & $3.26 \pm 0.50$ & $0.066 \pm 0.003$ & 16 & $3.66 \pm 0.03$ & $0.33 \pm 0.01$ & 0.99 \\
\hline
\end{tabular}


Table 3 Pearson correlation coefficients of different chemical and physical characteristics of particles of 11 crop residues, their maximum water content (MaxWC), minimal water content
(MinWC), time of diffusion to reach MaxWC and the propensity of the residues to undergo water recharge (b)

\begin{tabular}{|c|c|c|c|c|c|c|c|}
\hline & MaxWC & MinWC & Immersion time & Linear dry mass & Linear volume & Density & $\mathrm{b}$ \\
\hline Soluble & 0.29 & -0.52 & 0.09 & 0.08 & 0.14 & -0.49 & 0.17 \\
\hline Hemicellulose & -0.39 & -0.06 & -0.25 & -0.29 & -0.28 & 0.39 & 0.27 \\
\hline Cellulose & 0.29 & 0.46 & -0.02 & 0.09 & 0.08 & -0.15 & -0.11 \\
\hline Lignin & -0.26 & 0.30 & 0.18 & 0.11 & 0.03 & 0.40 & -0.41 \\
\hline NDF & -0.31 & 0.51 & -0.11 & -0.10 & -0.17 & 0.52 & -0.15 \\
\hline LCI & -0.26 & 0.26 & 0.17 & 0.10 & 0.01 & 0.37 & -0.41 \\
\hline Sol/Lig & 0.06 & -0.58 & -0.34 & -0.17 & -0.09 & -0.28 & $0.61^{*}$ \\
\hline $\mathrm{C} / \mathrm{N}$ & $0.65 *$ & 0.14 & 0.60 & $0.81 * *$ & $0.86 * * *$ & -0.56 & -0.31 \\
\hline MaxWC & - & - & - & 0.59 & $0.69 *$ & $-0.90 * * *$ & 0.13 \\
\hline MinWC & - & - & - & 0.23 & 0.19 & 0.21 & -0.31 \\
\hline Immersion time & - & - & - & 0.58 & 0.53 & -0.21 & $-0.85 * * *$ \\
\hline Linear dry mass & - & - & - & - & $0.98 * * *$ & -0.50 & -0.26 \\
\hline Linear volume & - & - & - & - & - & -0.60 & -0.21 \\
\hline Density & - & - & - & - & - & - & -0.15 \\
\hline
\end{tabular}

The numbers in bold indicate a significant correlation, with $n=11$ and $p=<0.05\left(^{*}\right),<0.01(* *)$ or $<0.001(* * *)$. ( - ) not applicable

$P=<0.001)$, and positively correlated with the SOL:LIG value $\left(r^{2}=0.61, P=<0.05\right)$ (Table 4$)$. There was no relationship observed between the MinWC and any of the chemical or physical characteristics. The closest relationship was observed between MaxWC and the relative density of the particles, which showed a negative linear

Table 4 Effect of the decomposition of maize stem particles $0.5 \mathrm{~cm}$ in length (T0.5), $2 \mathrm{~cm}$ in length (T2) and $5 \mathrm{~cm}$ in length (T5) that were undecomposed (day 0 ) or incubated in soil at $25^{\circ}$ $\mathrm{C}$ and sampled after 49 and 105 days to determine their chemical characteristics, total carbon (C), total nitrogen (N), Soluble, Hemicellulose, Cellulose and Lignin fractions, NDF content, relationship in the range of 0.1 (sunflower) to $0.6 \mathrm{gcm}^{-3}$ (alfalfa) (Fig. 3). The obtained porosity values rank the stem particles inversely to density due to Eq. 6, and porosity was strongly and positively correlated with MaxWC in the range of 0.6 (alfalfa) to 0.9 (sunflower) $\left(\mathrm{y}=7.0175 \times-3.2281, R^{2}=0.8013\right)$.

lignocellulose index (LCI), physical characteristics and density. The values were identical at time 0 for the 3 particle-size treatments, except for particle density. The values are the mean of 3 replicates, except for density determination with 8 replicates ( \pm standard errors $)$

\begin{tabular}{|c|c|c|c|c|c|c|c|c|c|c|c|}
\hline Duration incubation (days) & Treatment & $\begin{array}{l}\mathrm{C} \\
g / k g\end{array}$ & $\begin{array}{l}\mathrm{N} \\
g / k g\end{array}$ & $\mathrm{C} / \mathrm{N}$ ratio & $\begin{array}{l}\text { Soluble } \\
\mathrm{g} / \mathrm{kg}\end{array}$ & $\begin{array}{l}\text { Hemicel } \\
\mathrm{g} / \mathrm{kg}\end{array}$ & $\begin{array}{l}\text { Cellulose } \\
\mathrm{g} / \mathrm{kg}\end{array}$ & $\begin{array}{l}\text { Lignin } \\
\mathrm{g} / \mathrm{kg}\end{array}$ & $\begin{array}{l}\text { NDF } \\
g / k g\end{array}$ & LCI & $\begin{array}{l}\text { Density } \\
\mathrm{g} / \mathrm{cm}^{3}\end{array}$ \\
\hline \multirow[t]{3}{*}{0} & T0.5 & 464 & 2.9 & 160.0 & 136 & 258 & 489 & 117 & 864 & 0.13 & $0.13 \pm 0.01$ \\
\hline & $\mathrm{T} 2$ & & & & & & & & & & $0.12 \pm 0.02$ \\
\hline & $\mathrm{T} 5$ & & & & & & & & & & $0.10 \pm 0.02$ \\
\hline \multirow[t]{3}{*}{49} & T0.5 & 452 & 7.4 & 61.1 & 82 & 245 & 447 & 226 & 918 & 0.25 & $0.09 \pm 0.01$ \\
\hline & $\mathrm{T} 2$ & 481 & 7.4 & 65.0 & 89 & 255 & 461 & 195 & 911 & 0.21 & $0.08 \pm 0.01$ \\
\hline & $\mathrm{T} 5$ & 477 & 5.9 & 80.8 & 89 & 249 & 483 & 179 & 911 & 0.20 & $0.07 \pm 0.01$ \\
\hline \multirow[t]{3}{*}{105} & T0.5 & 489 & 9.0 & 54.3 & 166 & 177 & 326 & 331 & 834 & 0.40 & $0.07 \pm 0.01$ \\
\hline & $\mathrm{T} 2$ & 478 & 8.1 & 59.0 & 125 & 241 & 410 & 224 & 875 & 0.26 & $0.06 \pm 0.01$ \\
\hline & $\mathrm{T} 5$ & 484 & 9.3 & 52.0 & 121 & 243 & 437 & 199 & 879 & 0.23 & $0.07 \pm 0.01$ \\
\hline
\end{tabular}




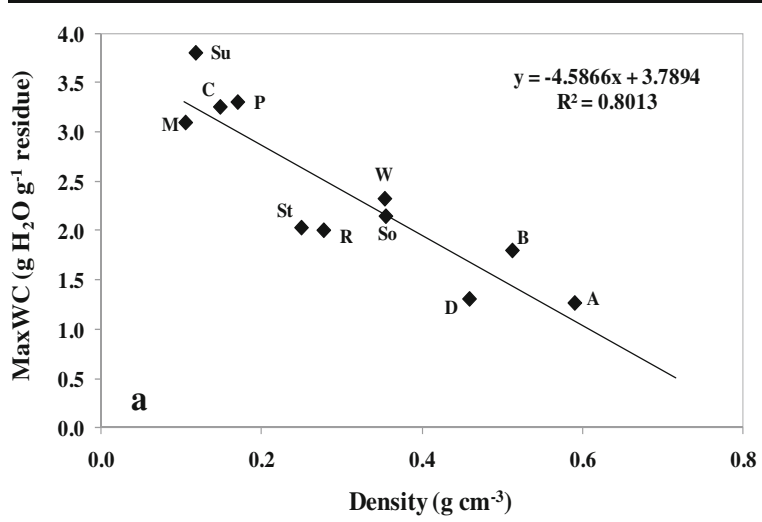

Fig. 3 Relationship between the maximum water content (g $\mathrm{H}_{2} \mathrm{O} \mathrm{g}^{-1}$ residue DM) and relative density $\left(\mathrm{g} \mathrm{DM} \mathrm{cm}^{-3}\right)$. The letters A, B, C, D, M, P, R, So, St, Su and W represent Alfalfa, Brachiaria, Canola, Dolichos, Maize, Pea, Rice, Soybean, Stylosanthes, Sunflower and Wheat, respectively

Effects of particle size and decomposition

\section{Changes in maize stem characteristics during decomposition}

The chemical characteristics of the maize stem particles recovered from soils changed over the sampling dates. The soluble NDS fraction decreased from $136 \mathrm{~g} /$ $\mathrm{kg} \mathrm{DM}$ at time 0 to $82-89 \mathrm{~g} / \mathrm{kg}$ on day 49 , regardless of the particle size and was observed to increase again on day 105. In the case of hemicellulose, the only significant change was observed for the $0.5 \mathrm{~cm}$ particle size on day 105. For cellulose, the main fraction of the maize stem initially represented $489 \mathrm{~g} / \mathrm{kg}$ of the $\mathrm{DM}$ and decreased significantly over time; the decrease was more pronounced for the $0.5 \mathrm{~cm}$ particle size. As decomposition progressed, there was an increase in the proportion of the lignin fraction, and the increase was greatest for the $0.5 \mathrm{~cm}$ particles. As a result of the concomitant changes in the different fractions, the NDF (proportion of cell wall material) decreased, while the LCI (the proportion of lignin in the plant cell wall) increased with increasing decomposition (Table 4).

The kinetics of water absorption was dependent on particle length; the EMC was obtained in $2 \mathrm{~h}$ for $0.5 \mathrm{~cm}$ particles, $12 \mathrm{~h}$ for $2 \mathrm{~cm}$ particles and $30 \mathrm{~h}$ for $5 \mathrm{~cm}$ particles. The resulting MaxWC did not vary significantly with particle size, with values of 2.4$2.8 \mathrm{~g} \mathrm{H}_{2} \mathrm{O} \mathrm{g}^{-1}$ dry residue being obtained. The relationship between residue particle length and the immersion time required to reach the EMC was linear $\left(y=6.1905 \times-0.8095, R^{2}=0.9993\right)$. The MaxWC of the decomposed particles was higher compared to undecomposed residues for the three particle sizes and increased with increasing particle size (Fig. 4). The standard deviations for MaxWC showed more variability for the decomposed particles compared with the undecomposed particles. The water retention curves obtained in the range of $\mathrm{pF} 0$ to $\mathrm{pF} 4.2$ showed that undecomposed residues retained more water than decomposed residues for the three particle sizes (Fig. 5). At $\mathrm{pF} 3$ and greater, the $0.5 \mathrm{~cm}$ decomposed particles sampled at days 49 and 105 lost approximately $96 \%$ of the initial water absorbed at $\mathrm{pF} 0$, while for the 2 and $5 \mathrm{~cm}$ particle sizes, the decomposed particles lost only $53 \%$ (day 49) and $59 \%$ (day 105) or $65 \%$ (day 49) and $68 \%$ (day 105) of their initial water, respectively (Fig. 5). Using Eq. 5, we calculated the distribution of the total porosity of the stem residues in different pore diameter classes. Figure 6 shows the $5 \mathrm{~cm}$ particle size as an example. At $t=0$, the distribution of pore size classes was fairly homogeneous. As decomposition progressed, the proportion of the volume of water in the pores of the larger class $(>29.12 \mu \mathrm{m})$ increased from $11 \%$ of the total water volume at $t=0$ to $37 \%$ at $t=49$ and $56 \%$ at $t=105$ (Fig. 6c). This pattern was similar for the other particle sizes (not shown).

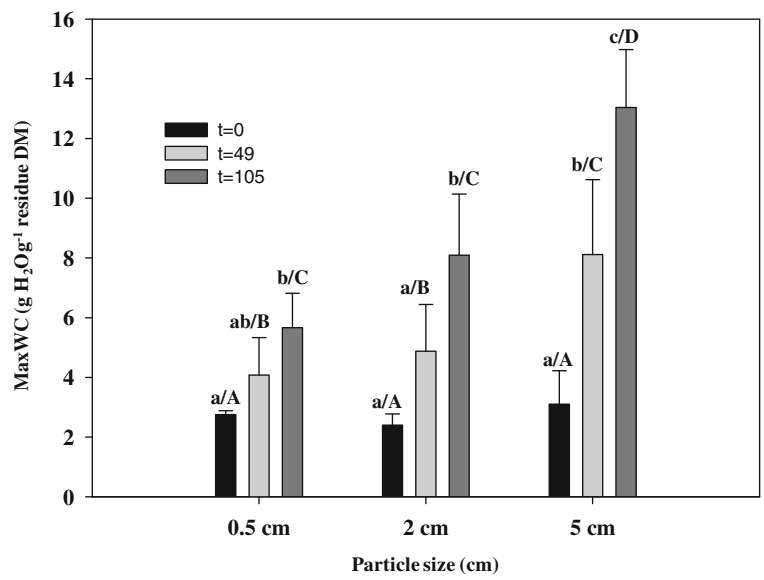

Fig. 4 Maximum water content for $0.5,2$ and $5 \mathrm{~cm}$ particle sizes at three times during decomposition: undecomposed $(t=$ 0 day), after 49 days of decomposition ( $t=49$ ) and after 105 days of decomposition $(\mathrm{d}=105)$. The data are given as the mean of 8 replicates per treatment and day of sampling. Lowercase letters $(\mathrm{a}, \mathrm{b}$ and $\mathrm{c}$ ) represent the differences between the incubation times for a given particle size, while the uppercase letters (A, B and C) represent the differences between the three particle sizes at a given incubation time 


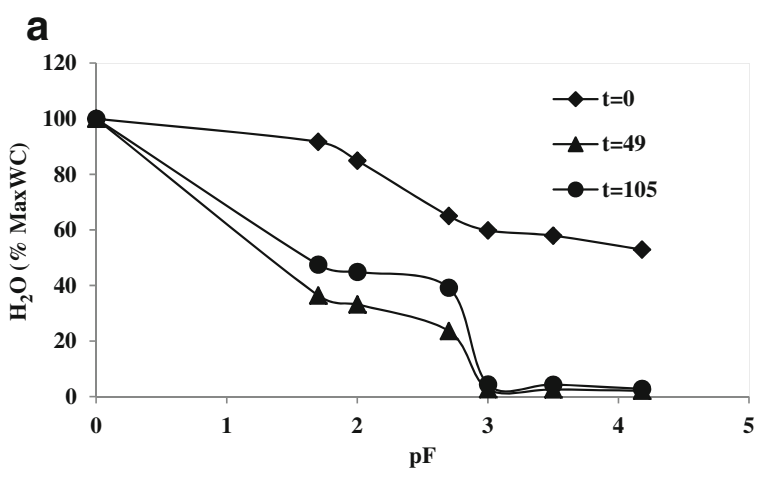

b

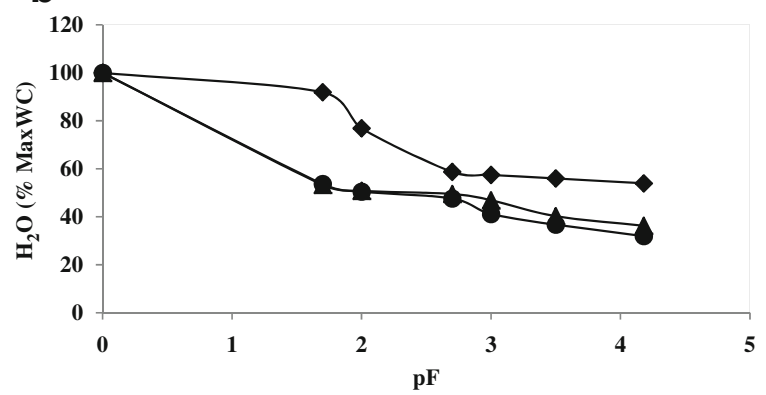

C

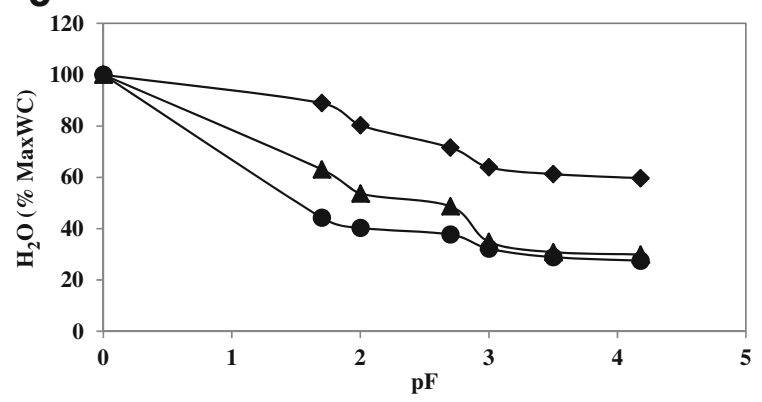

Fig. 5 Water retention curves for maize stem residues with lengths of $0.5 \mathrm{~cm}(\mathbf{a}), 2 \mathrm{~cm}$ (b) and $5 \mathrm{~cm}$ (c) on three sampling dates: $t=0$ (Black Diamond), after 49 days of decomposition, $t=$ 49 (Black Triangle) and after 105 days of decomposition, $t=105$ (Black Circle). The data are the mean of 3 replicates per treatment and day of sampling

\section{Relationships between maize particle characteristics and water storage}

The changes in the residue biochemical fractions due to decomposition (Table 4) were considered individually, but did not explain the observed changes in MaxWC (data not shown). Conversely, the residue MaxWC increased linearly with the LCI for a given particle size, with a steeper slope associated with increasing particle sizes from 0.5 to 2 and $5 \mathrm{~cm}$ (Fig. 7a). The density of the particles decreased with increasing decomposition (Table 4), showing a unique relationship

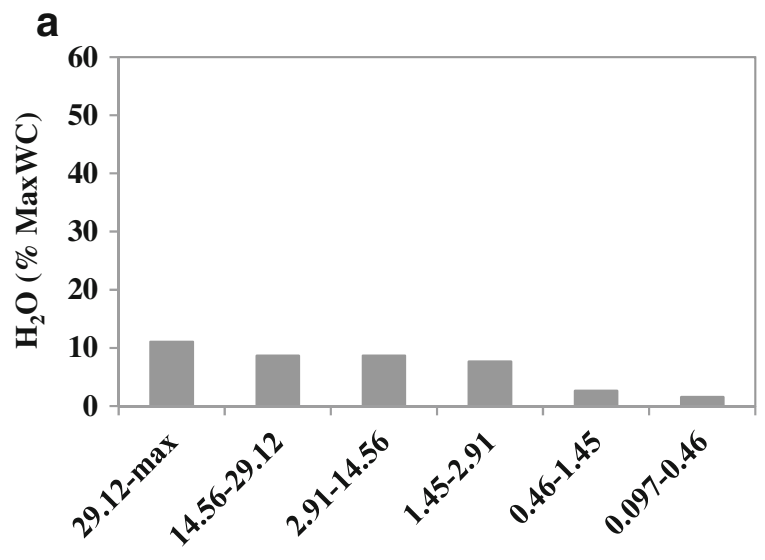

Pore size class $(\mu \mathrm{m})$

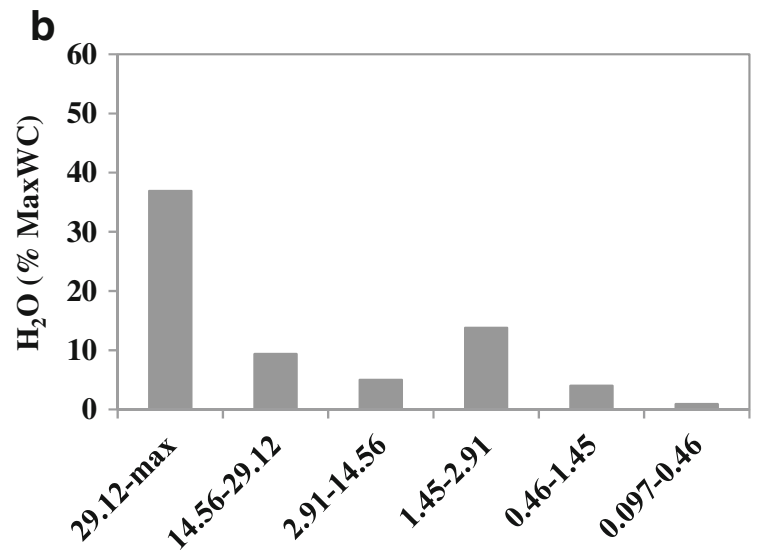

Pore size class $(\mu \mathrm{m})$

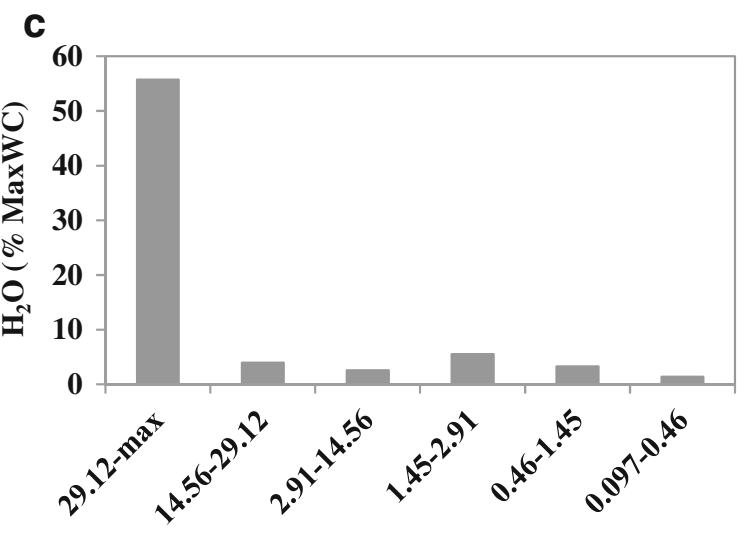

Pore size class $(\mu \mathrm{m})$

Fig. 6 Water distribution in pores of different diameter size classes for $5 \mathrm{~cm}$ particles, expressed as the percentage of maximal water content, on three sampling dates: (a) $t=0$, (b) $t=49$ and (c) $t=105$ days. The data are obtained from 3 replicates per treatment and day of sampling 

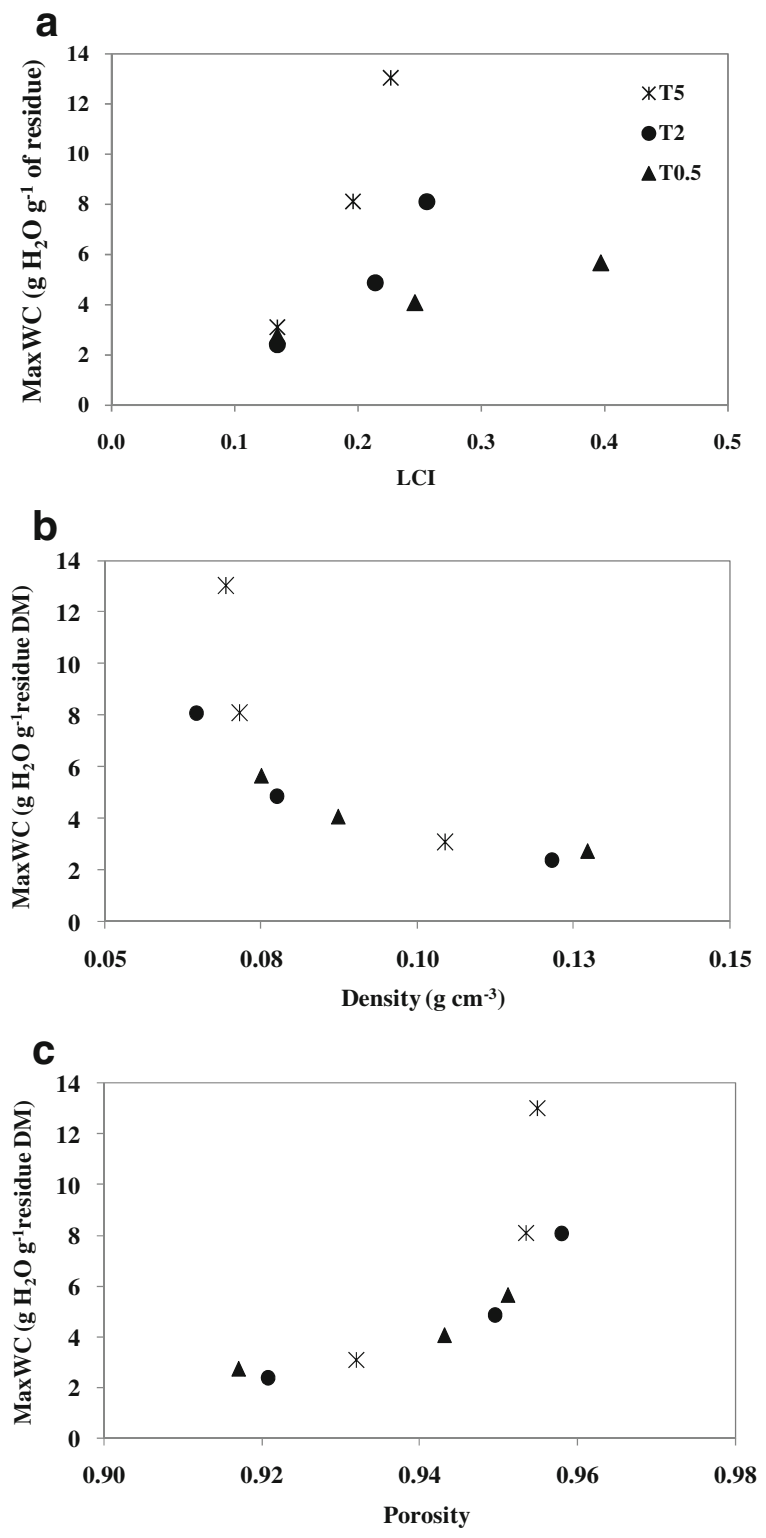

Fig. 7 Relationships between the maximal water content and the residue lignocellulose index LCI (a), residue relative density (b), and residue porosity (c), with (Asterisk) indicating $5 \mathrm{~cm}$ length particles, (Black Circle) indicating $2 \mathrm{~cm}$ length particles and (Black Triangle) indicating $0.5 \mathrm{~cm}$ length particles. The data are the mean of 8 replicates per treatment and day of sampling

with MaxWC, irrespective of the particle size and sampling time (Fig. 7b). Density and porosity are linearly correlated (Eq. 6), such that porosity increased with increasing decomposition. Consequently, MaxWC increased with increasing porosity, presenting a strong correlation, irrespective of the particle size treatment (Fig. $7 \mathrm{c} ; \mathrm{y}=0.000 \mathrm{e}^{32.969 \times}, R^{2}=0.792$ ).

\section{Discussion}

Several studies have been performed to evaluate the moisture-related properties of soil under mulch (Todd et al. 1991; Findeling et al. 2003). A number of studies have also evaluated the water retention properties of soil residue mixtures (Garnier et al. 2004). However, little information is available regarding the maximum and minimum water storage capacities of actual plant residues. It is important to understand these properties because the ability of crop residues to store water impacts water exchange between the soil, residue layer and the atmosphere. These exchanges influence both the water status of soil and the kinetics of the decomposition of the residues (Coppens et al. 2007). A limited number of studies have been conducted on plant residues, and consequently, different methods from different research fields were used in this study to investigate the water storage properties in "intact" plant stem residues. Indeed, much work has been performed in the wood and fiber industries examining the water storage properties of plant tissues. Ferrero (2003) adopted a capillary rise method to check the wettability of synthetic fibers; however, this method is not suitable for an intact stem residue because it would take several days to reach the equilibrium moisture content favoring decomposition, which would modify the storage properties. Therefore, we adopted the immersion method (Myrold et al. 1981; Quemada and Cabrera 2002) to determine the kinetics of absorption and the water holding capacities of plant residues. The relationships between the water storage characteristics and the physical properties were studied by (i) calculating the total porosity of plant tissues from the relative density, as proposed by Kellog and Wangaard (1969) for wood, and (ii) determining the subsequent effect of decomposition on the modification of the plant residue structure. The development of new pores was calculated from the retention curves using the pressure extractor method (Garnier et al. 2004), which allowed us to calculate the pore size distribution using the formula proposed by Cloutier and Fortin (1991) and to understand the relationships between decomposition and water storage.

In this study, we applied the principle of immersion, but we did not use a standard time for water saturation because underestimating the period of time would 
underestimate the MaxWC, while immersion for a longer time than is strictly required would favor alteration of the particles via decomposition. Obtaining the kinetics of absorption for crop residues also provides important parameters for modeling mulch residue decomposition, i.e. the maximum water content, minimal water content and the residue's propensity to undergo water recharge (Findeling et al. 2007). Calculation of parameter $b$ is of utmost importance in modeling studies addressing water dynamics in soils covered with decomposing residues because it aids in understanding the speed at which a given residue will absorb rain water and reach (or not) an equilibrium moisture content in accordance with the duration and intensity of rain. These characteristics are crucial to determine the amount of rain retained by mulch or transported into the soil by runoff. The ability of mulches to moisten and retain water under actual conditions of rain (amount and intensity), is to explore.

Impact of initial stem characteristics on water storage properties

The rate of water diffusion (expressed by the immersion time) varied greatly between the residues, and the pattern observed while reaching an equilibrium moisture content was not the same for all residues. Polymers usually follow the general diffusion law, or Fick's second law of diffusion (Fick 1855). The typical Fickian absorption curve contains an initial linear plot of M (penetrant mass) as a function of time $t$; with increasing $t$, an equilibrium is reached, which is smoothly equilibrated by the absorption curve (Van der Wel and Adan 1999). Some residues followed the typical Fickian absorption curve (e.g., Alfalfa and Canola), while a few deviated from this typical curve (e.g., Sunflower and Wheat). In the present study, it was observed that deviation from this typical curve (results not shown) could result from the biochemical and physical complexity of the material examined. This complexity arises from the heterogeneity induced by morphological and anatomical differences among the plant stems. Therefore, the organization of the plant residues (the geometry and anatomy of the plant organs), which is not considered in the present study, is probably crucial in the determination of a plant residue's propensity to undergo water recharge (Shane et al. 2000). The relationship between the immersion time necessary to reach the equilibrium moisture content and the $0.5,2$ and $5 \mathrm{~cm}$ particle sizes was confirmed using Washburn's equation, which predicted a linear relationship between the square of the advanced distance (h) and time (t) (Washburn 1921), further confirming the validity of the method used for measuring maximum water retention in this study.

The undecomposed plant residues absorbed a significant amount of water, and the maximal water content varied greatly between the eleven residue types, ranging from 1.28 to $3.81 \mathrm{~g} \mathrm{H}_{2} \mathrm{O} \mathrm{g}^{-1}$ residue DM. These values are consistent with the range of published values for known crop residues. Bartholomew and Norman (1946) observed that the maximum water storage for oat straw was $2.5 \mathrm{~g} \mathrm{H}_{2} \mathrm{O} \mathrm{g}^{-1}$ residue DM, while Myrold et al. (1981) obtained a value slightly higher than $3 \mathrm{~g} \mathrm{H}_{2} \mathrm{O} \mathrm{g}^{-1}$ residue DM for chopped wheat straw, and Quemada and Cabrera (2002) obtained values of 3.5 and $1.9 \mathrm{~g} \mathrm{H}_{2} \mathrm{O} \mathrm{g}^{-1}$ residue $\mathrm{DM}$ for clover and rye stems, respectively. The group showing the highest MaxWC values in the present study contained sunflower, pea, canola and maize stems. The second group consisted of wheat, rice, soybean, stylosanthes and brachiaria stems. Notably, these residues neither belong to the same botanical family nor exhibit the same morphological characteristics. Therefore, it is not possible to define a typology for the plant stems of these eleven residues based on their plant families or biochemical characteristics to explain the differences in the MaxWC values, which is a major accomplishment of this work.

Quemada and Cabrera (2002) suggested that the presence of soluble organic constituents in plant materials could determine their water storage characteristics. Pejic et al. (2008) investigated the individual influence of hemicellulose and lignin removal on the water uptake behavior of hemp fibers. In contrast to the findings of these researchers, we observed only two biochemical characteristics (the $\mathrm{C} / \mathrm{N}$ ratio and the soluble to lignin ratio) that were related to the water content properties of the residues. The $\mathrm{C} / \mathrm{N}$ ratio was positively correlated with MaxWC, but only because the two residues with the highest MaxWC values (sunflower and maize) also exhibited high $\mathrm{C} / \mathrm{N}$ ratios, and there was no significant difference in the $\mathrm{C} / \mathrm{N}$ ratio between the other residues. The $\mathrm{C} / \mathrm{N}$ ratio was also positively and strongly related to the dry mass and volume of the residues for the same reasons mentioned above. Wood and plant fibers containing cellulosic materials are all porous to a greater or lesser extent 
(Strømdahl 2000), and density, which is measured according to the quantity of the cell wall material contained in a specific volume of wood, is an index of the void volume or porosity (Hughes 1967). In this work, porosity is the only factor that explains the differences in the MaxWC between the stem residues. These findings agree well with results obtained earlier by Garnier and Laurent (1994) showing a close relationship between leaf water content and leaf density for 14 grass species. Conversely, small differences were observed between the crop residues based on the MinWC. The MinWC reflects the water adsorbed at accessible sites, rather than in cavities and intercellular spaces present in the heterogeneous structures of the crop residues filled with free water. The two groups of crop residues distinguished based on their MinWC do not correspond to any of the three groups discriminated based on MaxWC (see above), and no trend was detected regarding the MinWC level and the biochemical or physical characteristics of the crop residues. We propose that because MinWC primarily reflects polymer hygroscopy (Merdas et al. 2002; Bessadok et al. 2009), the contrast between the biochemical compositions of the stem particles is probably not sufficiently great to engender major differences. Therefore, a fixed value could potentially be used for modeling, irrespective of the plant residue type. Conversely, the MaxWC depends principally on the cell wall pores, cavities and cell lumens, e.g., residue macrostructure.

\section{Effect of decomposition on water storage characteristics}

In decomposition studies, it has been shown that smaller residue particles decompose faster than larger particles (Angers and Recous 1997; Matus et al. 1997). Thus, it is reasonable to hypothesize that smaller particles would be more structurally modified at a given sampling time during decomposition. Our results are consistent with this hypothesis, as the smaller particles (T0.5) were more physically and chemically modified during the 105-day incubation period. This increased decomposition of maize stems translated into a higher lignocellulose index and a lower density for the $0.5 \mathrm{~cm}$ particles than for the larger particles at the end of the incubation. The MaxWC increased with increasing decomposition for all particle sizes. This increased water storage could be explained by alteration of the physical and chemical structure of the particles during decomposition. The changes in physical and chemical features during decomposition are linked, as the decreases in the cellulose and hemicellulose contents arising through enzymatic processes result in increase in porosity within plant tissues (Maloney and Paulapuro 1999), which are susceptible to increased water absorption. This assumption is consistent with the increase in the volume of pores with larger diameters (29.5 $\mu \mathrm{m}$-max), as calculated using the water retention curves. However, the free water contained in the larger pores can be easily removed from the residues at low water pressures because it is not strictly bound to the residue. With the advancement of decomposition, the structure of the residue particles changes, and the type of interaction and the magnitude of the water interaction is strongly dependent on the polymeric structure (Van der Wel and Adan 1999). Dresboll and Magid (2006) also stated that the water storage capacity could be influenced by the extent of decomposition. We used the lignocellulose index (LCI) proposed by Herman et al. (2008) to express the concomitant changes in the plant polymers and found that the LCI and water storage were closely associated for a given maize-stem particle size. We hypothesize that the correlation between the LCI and the MaxWC was only indirect, as an increasing LCI reflects the duration of decomposition, which is tightly coupled to changes in the physical properties of the particles, i.e., their density and porosity. The results clearly showed that the observed changes in porosity could explain the changes in the MaxWC associated with increasing decomposition, irrespective of particle size. The rate of decomposition and the evolution of physical structure of stem particles during the decomposition were related specifically to the model "maize" in this experiment, and these changes are dependent on initial residues characteristics. But we believe that the conclusion regarding the decrease in tissue density with decomposition is applicable to all residues.

\section{Conclusion}

In this study, we identified the porosity of plant stem residues as the primary factor explaining the MaxWC across a range of chemical and physical parameters of plant stem residues obtained via varying the crop type, particle size or degree of decomposition. Porosity appears to be a reliable 
indicator for both decomposed and undecomposed residues. The porosity of stem residues was correlated with the density of the plant tissues, which varied greatly between residues, depending on the type of stem, e.g., its morphology and structure, which can be described qualitatively. For a given residue such as maize stem, decomposition altered the chemical and physical characteristics of the residue particles, increasing the proportion of lignin to other macromolecules and the maximal capacity to store water. Changes in density and porosity due to decomposition were responsible for this effect.

From an agricultural perspective, the results obtained in this study showed rather large variability in the plants' ability to retain water. Mulch can partially absorb rainfall water, depending on the amount of rain and its intensity, the propensity to undergo water recharge, and the biomass and thickness of the mulch. Thus, absorption is expected to increase with increasing mulch decomposition within the first months of decomposition according to our findings. This conclusion is consistent with previous observations that the water retained by decomposing residues be more available and free to undergo subsequent evaporation or infiltration into the soil. These results are also important from a modeling perspective. That means that the prediction of water storage in crop residues can be performed from a single variable (density) for different residues and for a given residue during decomposition, which also emphasizes the need for achieving a better understanding and better modeling of the relationship between the physical and chemical properties of plant residues to predict plant residue decomposition.

\begin{abstract}
Acknowledgments This work was funded through INRA and the PEPITES project (ANR Systerra, ANR-08-STRA-10), which provided a doctoral grant to Akhtar Iqbal. The authors would like to thank Dr. Pauline Défossez for fruitful discussions at the beginning of this work and Dr. B. Chabbert for her thorough review of an earlier version of this paper. We would also like to acknowledge G. Alavoine, O. Delfosse, S. Millon and L. Bechatta for their technical assistance and P. Thiébeau, J. Dussere and E. Scopel for providing the plant materials.
\end{abstract}

Open Access This article is distributed under the terms of the Creative Commons Attribution License which permits any use, distribution, and reproduction in any medium, provided the original author(s) and the source are credited.

\section{References}

Abiven S, Recous S, Reyes V, Oliver R (2005) Mineralisation of $\mathrm{C}$ and $\mathrm{N}$ from root, stem and leaf residues in soil and role of their biochemical quality. Biol Fertil Soils 42:119-128

Almeida G, Hernandez RE (2006) Changes in physical properties of tropical and temperate hardwoods below and above the fiber saturation point. Wood Sci Technol 40:599-613

Angers DA, Recous S (1997) Decomposition of wheat straw and rye residues as affected by particle size. Plant Soil 189:197-203

Bartholomew WV, Norman AG (1946) The threshold moisture content for active decomposition of some mature plant materials. Soil Sci Soc Am Proc 11:270-279

Bartholomew WV, Norman AG (1950) Moisture sorption by some common plant materials. Agron J 42:427-431

Baumhardt RL, Jones OR (2002) Residue management and tillage effects on soil-water storage and grain yield of dryland wheat and sorghum for a clay loam in Texas. Soil Till Res 68:71-82

Bertrand I, Chabbert B, Kurek B, Recous S (2006) Can the biochemical features and histology of wheat residues explain their decomposition in soil? Plant Soil 281:291-307

Bessadok A, Langevin D, Gouanve F, Chappey C, Roudesli S, Marais S (2009) Study of water sorption on modified Agave fibres. Carbohydr Polym 76:74-85

Bussiere F, Cellier P (1994) Modification of the soil temperature and water content regimes by a crop residue mulch: experiment and modeling. Agr Forest Meteorol 68:1-28

Callum ASH, Norton A, Newman G (2009) The water vapor sorption behavior of natural fibers. J Appl Polym Sci 112:1524-1537

Cloutier A, Fortin Y (1991) Moisture content-water potential relationship of wood from saturated to dry conditions. Wood Sci Technol 25:263-280

Coppens F, Garnier P, Findeling A, Merckx R, Recous S (2007) Decomposition of mulched versus incorporated crop residues: modelling with PASTIS clarifies interactions between residue quality and location. Soil Biol Biochem 39:2339-2350

Cornelissen JHC, Lavorel S, Garnier E, Diza S, Buchmann N, Gurvich DE, Reich PB, Steege HT, Morgan HD, Heijden MGAVD, Pausas JG, Poorter H (2003) A handbook of protocols for standardised and easy measurements of plant functional traits worldwide. Aust J Bot 51:335-380

Dresboll DB, Magid J (2006) Structural changes of plant residues during decomposition in a compost environment. Bioresour Technol 97:973-981

Ferrero F (2003) Wettability measurements on plasma treated synthetic fabrics by capillary rise method. Polym Test 22:571-578

Fick A (1855) On liquid diffusion. Philos Mag J Sci 10:31-39

Findeling A, Ruy S, Scopel E (2003) Modeling the effects of a partial residue mulch on runoff using a physically based approach. J Hydrol 275:49-66

Findeling A, Garnier P, Coppens F, Lafolie F, Recous S (2007) Modelling water, carbon and nitrogen dynamics in soil covered with decomposition mulch. Eur J Soil Sci 58:196-206

Fuentes M, Hidalgo C, Etchevers J, De León F, Guerrero A, Dendooven L, Verhulst N, Govaerts B (2011) Conservation 
agriculture, increased organic carbon in the top-soil macroaggregates and reduced soil $\mathrm{CO} 2$ emissions. Plant Soil 355:183-197

Garnier P, Ezzine N, De Gryze G, Richard G (2004) Hydraulic properties of soil-straw mixtures. Vadose Zone J 3:714-721

Garnier E, Laurent G (1994) Leaf anatomy, specific mass and water content in congeneric annual and perennial grass species. New Phytol 128:725-736

Goering HK, Van Soest PJ (1970) Forage fibre analyses. US Government Printing Office, Washington DC, Agric Handb No 379, USDA-ARS

Herman J, Moorhead D, Berg B (2008) The relationship between rates of lignin and cellulose decay in aboveground forest litter. Soil Biol Biochem 40:2620-2626

Hughes JF (1967) Density as an index of wood quality with special reference to the development of rapid and efficient methods of estimating density. In: Proceedings of the Tropical Forestry Meeting by Commonwealth Forestry Institution. Oxford, pp 1-4

Kellog RM, Wangaard FF (1969) Variation in the cell-wall density of wood. Wood Fiber Sci 1:180-204

Kollmann FFP, Cote WA (1968) Principles of wood science and technology (I). Solid Wood. Springer, Berlin, p 592

Lineres M, Djakovitch JL (1993) Caractérisation de la stabilité biologique des apports organiques par l'analyse biochimique. In: Decroux J, Ignazi JC (eds) Matières organiques et agricultures. Gemas-Comifer, Paris, pp 59-68

Machinet GE, Bertrand I, Chabbert B, Recous S (2009) Decomposition in soil and chemical changes of maize roots with genetic variations affecting cell wall quality. Eur J Soil Sci 60:176-185

Maloney TC, Paulapuro H (1999) The formation of pores in the cell wall. J Pulp Paper Sci 25:430-436

Matus FJ, Retamales JB, Sanchez (1997) Effect of particle size and quality of pruning wood residue of Asian pear (Pyrus pyrifolia and Pyrus communis) on A-and Nmineralization in soils of contrasting textures. Acta Hortic Sin 475:327-337

Merdas I, Thominette F, Tcharkhtchi A, Verdu J (2002) Factors governing water absorption by composite matrices. Compos Sci Technol 62:487-492
Myrold DD, Elliot LF, Papendick RI, Campbell GS (1981) Water potential-water content characteristics of wheat straw. Soil Sci Soc Am J 45:329-333

Quemada M, Cabrera ML (2002) Characteristic moisture curves and maximum water content of two crop residues. Plant Soil 238:295-299

Pejic BM, Kostic MM, Skundric PD, Praskalo JZ (2008) The effects of hemicelluloses and lignin removal on water uptake behavior of hemp fibers. Bioresour Technol 99:7152-7159

Savabi M, Stott D (1994) Plant residue impact on rainfall interception. ASAE 37:1093-1098

Shane MW, McCully ME, Canny MJ (2000) The vascular system of maize stems revisited: Implications for water transport and xylem safety. Ann Bot 86(2):245-258

Strømdahl K (2000) Water sorption in wood and plant fibres. PhD Thesis, Department of Structural Engineering and Materials, Technical University of Denmark, Series R, No 78

Todd RW, Klocke NL, Hergert GW, Parkhurst AM (1991) Evaporation from soil influenced by crop shading, crop residue and wetting regime. Trans ASAE 34:461-466

Tostado A (1996) Etude et modélisation de l'effet des paillis sur le bilan hydrique-Le cas du semis direct sous paillis au Mexique. DEA report, CIRAD, MontpellierCiudad Guzman, p 82

Trinsoutrot RS, Bentz B, Line'res M, Cheneby D, Nicolardot B (2000) Biochemical quality of crop residues and carbon and nitrogen mineralization kinetics under nonlimiting nitrogen conditions. Soil Sci Soc Am J 64:918-926

Tsoumis GT (1991) Science and technology of wood: structure, properties, utilization. Van Nostrand Reinhold, New York, p 494

Usta L (2003) Comparative study of wood density by specific amount of void volume (Porosity). Turk J Agric For 27:1-6

Van der Wel GK, Adan OCG (1999) Moisture in organic coatings - a review. Prog Org Coat 37:1-14

Washburn EW (1921) The dynamics of capillary flow. Phys Rev 17:273-283

Zhang Y, Pitkänen L, Douglade J, Tenkanen M, Remond C, Joly C (2011) Comparative wheat bran arabinoxylans: chemical structure and film properties of three isolated fractions. Carbohydr Polym 86:852-859 